monophasic cycle, for no separate first phase exists in these, the whole cycle consisting of a series of changes comparable only with pseudo-pregnancy. Menstruation is nothing else than the termination of pseudo-pregnancy, and has nothing whatsoever to do with cestrus and ostrous bleeding. The complete monophasic cycle is to be compared with the second phase of the diphasic cycle.

In all monophasic animals, however, the $a$-factor plays an important rôle. Every stage of pseudopregnancy (pre-menstruum) and pregnancy corresponds to a certain level of the a-factor (Zondek, Smith, etc.). By raising the level of the a-factor artificially, there is produced a stage more advanced than that appropriate to the stage of development of the embryo.

B. P. Wiesner.

Animal Breeding Research Department, University of Edinburgh.

\section{Prices of Periodical Scientific Publications}

THE high prices that are being charged by certain Continental publishers for scientific journals issued by them brings up the very serious question of the steps which must be taken by learned societies, institutions, and individuals against these extraordinary prices. The journals are wanted for reference by research workers all over the world, but their prohibitive prices are in many cases making it impossible for most institutions to continue subscribing to them, while for a great majority of individual workers to purchase single volumes at $£ 77 \mathrm{~s}$. to $£ 88 s$. is absolutely out of the question. A great amount of material is apparently available for publication, as three to four volumes of various journals are issued every year. The prices for subscription of different volumes are not on a regular rate, but an arbitrary price is fixed for each part of the different volumes. This results in the subscription for various journals amounting to as much as $£ 20$ a year.

I give below a few cases with the actual printed prices of the volumes for the year 1927. Ergebnisse der Anatomie und Entwicklungsgeschichte, which up to vol. 22 for 1914 (issued in 1916) was published by J. F. Bergmann, Wiesbaden, and was taken over by the combine of publishing firms of J. F. Bergmann, Munich, and Julius Springer, Berlin. It now forms the third part of Zeitschrift für die gesamte Anatomie. The last volume, 27, issued in November 1927, consists of 1104 pages with 271 text-figures; there are no plates. The price of this volume is 168 Reichsmarks, or roughly $£ 88 s$. The price of three volumes of Zeitschrift für Anatomie und Entwicklungsgeschichte, issued during 1927 and forming part 1 of the abovementioned series, comes to Reichsinarks 405 , or $£ 205 s$.; the price per volume would work out roughly at $£ 7$. The volumes of Wilhelm Rouxs Archiv für Entwicklungsmechanik, issued during 1927, cost Reichsmarks 380 , or $£ 19$, and the price of a single volume varies between $\mathfrak{£ 5} 5 s$. and $£ 7$. The two volumes of Zeitschrift für Zellforschung und mikroskopische Anatomie, issued during 1927, cost Reichsmarks 240 , or $£ 12$.

The above publications are all issued either by Bergmann and Springer or by Springer alone. The case of Archiv für Naturgeschichte, issued by the Nicolaische Verlag, Berlin, is no better. Of the two volumes of this serial, more than a dozen parts are issued every year at an average price of Reichsmarks 30 to 36 , and the average cost of the serial works out

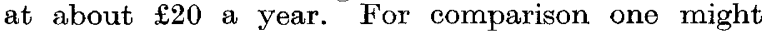
refer to journals like Zoologische Jahrbücher or Archiv für Protistenkunde, prices for the different volumes of which vary between 60 and 80 marks, or $£ 3$ to $£ 4$. The size of text and number of illustrations, both in the form of text figures and plates of these serials, would compare very favourably with any of the journals mentioned above.

The cost of printing has undoubtedly gone up since the War, but are these exorbitant prices justified? And can various institutes and societies, with their moderate grants or income, continue subscribing to these journals? I am afraid it is practically impos. sible for many institutions, like the Zoological Survey of India, which has complete sets of all the journals mentioned above, to continue subscribing to them much longer, unless the prices are materially reduced or their library grants are increased. In the interest of workers, could not various bodies like the Royal Society of London, the Zoological Society of London, and other similar institutions, take up the matter and consider what steps can possibly be taken to deal with the difficult situation?

Zoological Survey of India,

Baini Prashad.

Indian Museum, Calcutta.

The Oldoway Skull.

I HAVE recently returned from Germany, where by the kindness of Dr Hans Reck I was enabled to examine the Oldoway skull and skeleton found by him in 1913 in what was then German East Africanow Tanganyika Territory-and I have also fully discussed the geological and palæontological evidence as to its age with Dr. Reck himself.

The object of my visit was to see how nearly the Oldoway skull compared with, or how it differed from, the fossil human skulls which I brought back from Elmenteita, Kenya Colony (see Nature, July 16,1927, p. 85)

With Dr. Reck's permission I am able to make the following statement about the Oldoway skull, though of course I may not give any measurements, as Prof. Mollison of Munich is now preparing a detailed report of the skull and skeleton for publication.

All the following statements are the result of my own personal examination of the skull and of my discussion with Dr. Reck.

(1) The Oldoway skeleton lay in a crouched position on its right side beneath undisturbed alluvial deposits belonging to the last pluvial period. The crouched position of the body certainly suggests burial, but if it was a burial it was quite certainly not from the present land surface, but from an earlier surface, for at least 3 metres of undisturbed alluvial strata lay above it. Dr. Reck inclines to the idea that the body became embedded when the deposits were forming under marshy conditions, for no trace of even a shallow grave was found.

(2) The undisturbed deposits lying above and below the skeleton were very rich indeed in mammal. ian remains. These, while including a number of forms such as eland and oryx, which are indistinguishable from living species, nevertheless consist-so Dr. Reck tells me-to more than 50 per cent. of extinct fauna. The latter includes a number of hitherto unknown genera and species of antelope; a new sheep; numerous remains of an elephant closely allied to Elephas antiquus which has been named Elephas antiquus Recki; extinct hippopotamus and rhinoceros; and a three-toed horse closely allied to hipparion. Despite the last-mentioned animal-which he considers as a survival from Pliocene or earlier times-Reck regards the deposit as belonging to the end of the Pleistocene.

(3) The human skull from Oldoway very closely resembles some of my fossil skulls from Elmenteita, which, I suggest, also belong at latest to the beginning

No. 3048, VoL. 121] 